\title{
Design and Construction of Low Cost Electronic Digital Integrator for Gas Chromatography
}

\author{
Ichiro TAKEDA
}

2 th Division, National Chemical Laboratory for Industry ; Honmachi, Shibuya-ku, Tokyo 151 Japan

A simple digital integrator for gas chromatography was designed, and details on the performance and the electrical circuits of the unit are described.

The voltage output from gas chromatograph was invertedly amplified by 100 times using $\mu \mathrm{A}-741$ type operational amplifier, then fed into the charge-balancing type voltage-frequency converter and the output pulse train was counted by integrated circuits (SN7490 N) and displayed by 5 digit Nixie tubes.

As valley senser type peak detector was also attached to the integrator, the display could be read from the memory of the integrals of the former peak, after recognition of the next peak elution.

On memorizing integrals of the former one by hand and by means of push button switch operation, the display could be read from the counter, as pules train was counted.

The circuit diagrams are shown in Figs. 2, 3, 4, and the linearity evaluation data of the voltagefrequency converter are shown in Table 1.

As for the gas chromatographic analysis, the precision and reproducibility of the individual measurement were good, as shown in Table 2 and the cost of construction of the unit was about $1 / 20$ that of the commercial one.

（日本化学会誌, 1974, (2), p. 287～291）

\section{ハイドロボレーションーメタノリシスを利用した オレフィンの定量法}

（1973 年 7 月 2 日受理）

尾崎博 己*. 大滝俊武**. 蒔田道司*. 鈴木 章***

ハイドロボレーションを利用して炭化水素混合物中のオレフィン含有量を定量する方法について報告 した。すなわち炭化水素混合物に所定量のボランを加えてハイドロボレーションしたのち，メタノール を加光過剩ヒドリドを分解し, 発生する水素量から C-C 二重結合の含有量を求めた。本法によればア ロマティックスが共存する場合でもオレフィン含有量の正確な分析が可能である。

つぎに，本方法を用いて石油系重質油を熱分解して得られる留出油を分析し，試料中に含有されるオ レフィン量を測定した。さらに, ケイ兆指示薬吸着法（FIA 法）と本法を組み合わせてモノオレフィ ン量とジンレフィン量を求める方法についても検討した。

\section{1 緒 言}

パラフィン, オレフィンおよびアロマティックスの混合物は，

ワックスや石油系重質油の熱分解，パラフィンの脱水素などによ

り得られる。これらに含有されるオンフィンは, オキソアルコー

*日本鉱業株式会社中央研究所, 335 戸田市新曾南

** 日本鉱業株式会社石油事業本部，107 東京都港区赤坂桨 町

*** 北海道大学工学部応用化学教空, 060 札帽市北 13 条西 8 丁目
ル，カルボン酸，アミンおよびアルキルベンゼンスルホナート用 の工業原料として重要なものであることから，前記混合物中にお けるオレフィンの含有量を正確に分析することが必要とされる。 この目的のためガスクロマトグラフィー（以下 GLC と略記する） を用い適当な条件を選ぶことにより各成分の分析が行なわれてい るが，前記混合物のよらに異性体の多いものでは，ピークの重な りが多く，GLC のみでオレフィン含有年を求めることは困難で ある。一方，赤外吸収スペクトルを利用する方法 ${ }^{112)}$ 6考えられ

1) E.L.Saier, A.Pozetsky, N.C.Coggeshall, Anal.Chem., 26, 1258(1954). 
るが，前記混合物のよらに多くの異性体を含むオレフィンについ て正確な検量線を求めることあ困難である。

臭素価法3)，ヨウ素価法(4および FIA 法5) すオンフィンの定量 に用いられるが，これらの方法では有色の炭化水素混合物中のオ レフィンを定量することが困難である。さらに, 試料中にアロマ ティックス，イソオレフィンが含有される場合には臭素価法扰よ びョウ素価法は，真の值より大さな值を与える傾向にある。

著者らは既報)で，ハイドロボレーションにより，オレフィン とボラン $\left(\mathrm{BH}_{3}\right)$ が定量的に反応すること，およびハイドロボレ ーションーアルカリ性過酸化水素酸化-GLC.法により直鎖パラフ ィンと直鎖オレフィンを定量する方法について報告した。今回 は，オレフィンにボランを反応させたのち、メタノールを加充， 過唾ヒドリドを分解し, 発生する水素量から, 不飽和二重結合の 数を測定する分析法を検討したのでここに報告する。

\section{2 実：験}

\section{1 試 萩}

用いた試薬の純度はつぎのとおりである。

\begin{tabular}{|c|c|c|}
\hline 試薬名 & 度 & \\
\hline$n$-ドデカン & 試薬特級（純度 $98 \%$ 以上）。 & 東京化成製 \\
\hline ードデセン & 試薬（純度 $99.86 \%$ 以上） & 三菱化成製 \\
\hline ーテトラデカン & 試薬 1 級（純度 $99 \%$ 以上） & 東京化成製 \\
\hline タシェン & 試薬（純度 $96 \%$ 以上） & 東京化成製 \\
\hline ル & 試楽特級（純度 98\% 以上） & 関東化学制 \\
\hline & 試薬特䄲（純度 $98 \%$ 以上） & 東京化成基 \\
\hline
\end{tabular}

ボランのテトラヒドロフラン溶液（濃度は $2 \mathrm{mmol} / \mathrm{ml}$ の $\mathrm{BH}_{s}$ に相当する) は Organic Reactions 記載の方法7)によって調製 した。

\section{2 実験装瞕}

図 1 に実験装置を示した。反応容器として窒素の導入管および ガスビュレットを直結した $200 \mathrm{~m} l$ の枝付さフラスコを用い,ガ スビュレット内の液体にはボランに不活性な $n$-テトラデカンを 用いた。カキマゼにはマグネティックスターラーを使用した。な

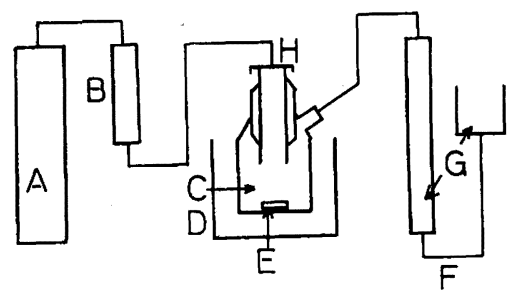

Fig. 1 Apparatus for borane method

A : Nitrogen cylinder, B : Silicagel column, C : Reactor, D : Water bath, E: Magnetic stirrer, F: Gas buret, G : n-Tetradecane, H : Cap

2) E. L.Saier, L.R. Cousins, M.R.Basila, Anal. Chem., 35, 2219(1963).

3) JIS K 2543(1965).

4) JIS K 0070(1966).

5) JIS K 2536(1969).

6) 大滰俊武, 尾崎博巳, 矢田直樹, 伊藤光臣, 鈴木 章, 日 化, 1972, 934 .

7) G. Zweifel, H.C. Brown, Org. Reactions, 13, 1(1963).
怙，この反応は発熱反応であるから，系内の温度を一定にするた めにフラスコを水で泠却した。また，窒素の導入就よび試料の導 入はセラムキャップを通じて注射針により行なった。

2.3 ハイドロボレーションおよびメタノリシス

反応容器およびガスビュレット内を窒素需囲気としたのち, 水 冷下に約 $2.5 \mathrm{~g}$ の陚料を精科して注入した。つぎにテトラヒドロ フラン (以下 $\mathrm{THF}$ と略記する) を $5 \mathrm{ml}$ 加克, 10 20 分間放 置してガスビュレットの目盛が一定になったときの目盛 $\left(a_{1} \mathrm{~m} l\right)$ を読んだ。つぎにボランの THF 溶液 $3 \mathrm{ml}$ (6.00 $\mathrm{mmol}_{\text {の }} \mathrm{BH}_{3}$ に相当する）を加充，10 分間かきまぜながらハイドロボレーシ ョンを行なったのち, メタノールを $3 \mathrm{ml}$ 加光過剩のとドリド $(b-\mathrm{H}, b=1 / 3 \mathrm{~B})$ を分解して水素を発生させ，その発生が完了し たのちのガスビュレットの目盛 $\left(a_{2} \mathrm{~m} l\right)$ を読み, $\left(a_{2}-a_{1}-6\right) \mathrm{m} l$ を発生水素量とした。

\section{4 奥素 価}

JIS K 2543(1965) によった。

\section{5 ヨウ素価}

JIS K 0070(1966) によった。

2.6 ヶイ光指示薬吸着法 (以下 FIA 法と略記する)

JIS K 2536(1969) によった。

\section{3 実験結果亡考察}

\section{1 ハイドロボレーションとメタノリシスによる定量法}

オレフィンを含有する炭化水素混合物試料に所定量のボランを 加えて, ハイドロボレーションしたのち, メタノールを加え, 過 剩ヒドリド $(b-\mathrm{H})$ を分解する。そのさい, 発生する水素量から オレフィン量を求めるのが, 本分析法の原理である。

$$
\begin{gathered}
b-\mathrm{H}+\mathrm{R}_{1}-\mathrm{CH}=\mathrm{CH}-\mathrm{R}_{2} \longrightarrow \mathrm{R}_{1}-\mathrm{CH}_{2}-\stackrel{b}{\mathrm{C}} \mathrm{H}-\mathrm{R}_{2} \\
b-\mathrm{H}+\mathrm{CH}_{3} \mathrm{OH} \longrightarrow \mathrm{H}_{2}+\mathrm{CH}_{3} \mathrm{Ob} \\
\text { ここで, } \mathrm{R}_{1} \text { はアルキル基 } \\
\mathrm{R}_{2} \text { はアルキル基または } \mathrm{H}
\end{gathered}
$$

すなわち，予想されるオレフィン含有量に対し，過剩のボランを 炭化水素混合物試料に加えて，オレフィンをアルキルボランに変 換する（(1) 式)。つぎに，メタノールを加えて，過剩ヒドリド (b-H) を完全に分解し（(2) 式），そのさい発生する水素量 $\left(V_{1} \mathrm{~m} l\right)$ を測定する。上記分析に用いたのと同じ量のボランを用 いて空実験を行ない，そのさい発生する水素量 $\left(V_{0} \mathrm{~m} l\right)$ を求め る。試料 $100 \mathrm{~g}$ によって消費されるヒドリドのモル数を次式から 算出し、これをボラン価と定義する。

$$
\begin{gathered}
\text { ボラン価 }(\mathrm{mol} / \text { 試料 } 100 \mathrm{~g})=\left(V_{0}-V_{1}\right) \times 273 /(273+t) \\
\quad \times 1 / 224 \times 1 / W \\
\text { ここで, } V_{0}: \text { 空実験の発生水素量 }(\mathrm{m} l) \\
V_{1}: \text { 過剩ヒドリドからの発生水素量 }(\mathrm{m} l) \\
t: \text { 室温 }\left({ }^{\circ} \mathrm{C}\right) \\
W: \text { 試料重量 }(\mathrm{g})
\end{gathered}
$$

モノオレフィンの場合には, (1) 武のハイドロボレーション により $1 \mathrm{~mol}$ のヒドリド (b-H) が $1 \mathrm{~mol}$ のモノオレフィンK 付加する。ジオレフィンの場合には, $2 \mathrm{~mol}$ のヒドリドが $1 \mathrm{~mol}$ のジオレフィンに付加する。 
したがって，モノオレフィンの場合は，

$$
\text { ボラン価ニモノオレフィンのモル数/試料 } 100 \mathrm{~g}
$$

ジオレフィンの場合は,

ボラン価 $=2 \times$ ジオレフィンのモル数/試料 $100 \mathrm{~g}$

モノオレフィンとジオレフィンの混合物の場合は,

$$
\begin{aligned}
\text { ボラン価= } & (モ / \text { オンフィンのモル数 }+2 \times \text { ジオレ } \\
& \text { フィンのモル数 }) / \text { 試料 } 100 \mathrm{~g}
\end{aligned}
$$

を表わす。

\section{2 ドテカンとドデセンの既知混合物の分析}

1ードデセンと $n$-ドデカンを既知量混合した試料を本ボラン法 により分析し，その 1-ドデセンの定量結果を表 1 に示した。

相対誤差は $\pm 2 \%$ 以内であり，その精度は，臭素価法 ${ }^{3}$ ， ヨウ 素価法) 招よび FIA 法(5) に規定される精度から判断して，十分正 確であるといえる。

3.3 ボラン法, FIA 法, 臭素価法およびヨウ素価法によるオ レフィン定量結果の比較

1-ドデセン, $n$-ドデカンおよび $\alpha$-メチルナフタレンを表 2 の ように既知量混合した試料にういて, ボラン法, FIA 法 (ケイ光 指示薬吸着法)，臭素価法怙よびョウ素価法により，オレフィン を定量し，その結果を比校した。FIA 法による分析結果は，容 量パーセントで測定されるから，测定值に各成分の比重を乘じて 重量パーセントに換算した。また，ボラン法，臭素価法特よびョ ウ素価法の場合にはモル数で求められるから，測定值に 1-ドデ センの分子量を乘じて，1-ドデセンの重量パーセントを算出し た。結果を表 3 に示す。試料Aのように, アロマティックが含ま

Table 1 Accuracy of borane method

\begin{tabular}{cccc}
$\begin{array}{c}\text { Sample } \\
\text { No. }\end{array}$ & $\begin{array}{c}\text { Theoretical } \\
a\end{array}$ & $\begin{array}{c}\text { Found } \\
b\end{array}$ & $\begin{array}{c}\text { Relative } \\
\text { error }(\%) \\
(b-a) / a \\
\times 100\end{array}$ \\
\hline 1 & 63.1 & 63.8 & +1.1 \\
2 & 23.2 & 23.1 & -0.4 \\
3 & 10.5 & 10.7 & +1.9
\end{tabular}

Table 2 Weight ratios of mixed samples for analyses

\begin{tabular}{lccc} 
Composition & $\begin{array}{c}\text { Sample A } \\
(\text { wt } \%)\end{array}$ & $\begin{array}{c}\text { Sample B } \\
(\text { wt } \%)\end{array}$ & $\begin{array}{c}\text { Sample C } \\
(\text { wt } \%)\end{array}$ \\
\hline 1-Dodecene & 20.0 & 30.0 & $1.6^{a)}$ \\
Inner dodecenes & 0.0 & 0.0 & $23.4^{a)}$ \\
n-Dodecane & 40.0 & 70.0 & 75.0 \\
$\alpha$-Methylnaphthalene & 40.0 & 0.0 & 0.0
\end{tabular}

a) This mixture of 1-dodecene and inner dodecenes was obtained by isomerization of 1-dodecene. The ratio of $\alpha$-olefin to inner olefins was previously reported ${ }^{6}$.

Table 3 Analytical results of olefin contents for the mixed samples shown in Table 2 by various methods

\begin{tabular}{lccc} 
Method & $\begin{array}{c}\text { Sample A } \\
(\mathrm{wt} \%)\end{array}$ & $\begin{array}{c}\text { Sample B } \\
(\mathrm{wt} \%)\end{array}$ & $\begin{array}{c}\text { Sample C } \\
(\text { wt \%) }\end{array}$ \\
\hline Borane method & 20.1 & 30.1 & 24.5 \\
Fluorescent indicator & 19.8 & 30.5 & 24.6 \\
$\quad$ adsorption method & 29.6 & 30.7 & 26.7 \\
Bromine method & 23.0 & 30.4 & 26.1 \\
Iodine method & & &
\end{tabular}

れる場合には，臭素価法とヨウ素価法では真の值より大きな値が 得られた。これに対して，ボラン法および FIA 法によれば， ア ロマティックの影響を受けずにオレフィン量が十分正確に定量さ れることがわかった。

\section{4 熱分解油中のオレフィンの分析}

石油系重質油を熱分解して得られる留出油 [沸点範囲（170 $\left.\left.230^{\circ} \mathrm{C} / 760 \mathrm{mmHg}\right)\right]$ について, ボラン法, 臭素価法およびヨウ素 価法の各法により，オレフィンの定量を行ない, その結果を表 4 に示した。臭素価法およびョウ素価法の值がボラン価より大きく でているのは，熱分解油中にアロマティックスが $40 \%$ 程度含有 されているためであると考えられる。

\section{5 炭化水素混合物中のジオレフィンの分析}

ジオレフィンの分析法としては，従来，共役ジェンを定量する 無ホマレイン酸価試験方法致が知られているが，この方法におい ては，共役ジェンのほかにアントラセン類およびビニル芳香族化 合物す無水マレイン酸と反応し定量を妨害する。また共役ジェン 以外のジェンは，無水マレイン酸と定量的には反応しないことも 知られている。したがってこの方法は，一般的なジェンの測定法 としては十分とはいえない。そこで著者らは，FIA 法において ジェンが芳香族分として定量されることぎ着目し，ボラン法と FIA 法を組み合わせて，ジオレフィンを定量する方法について 検討した。

表 5 に示す割合のトルエン, 1,7-オクタジェン, 1-ドデセンお よび $n$-ドデカンを含有する標準試料を調製し，この標準試料を FIA 法により分析した。その分析結果およびそれらに比重を乗 じて換算した重量パーセントを表 6 に示した。

つぎに，同じ標淮試料のボラン価を測定し，その結果を表 7 に 示した。

つぎに（7）式を用いてジオレフィンのモル数を計算し，その 結果を表 8 に示した。

$$
\begin{aligned}
& \text { ジオレフィンのモル数 }(\mathrm{mol} / / \bar{t} \text { 料 } 100 \mathrm{~g})=(\mathrm{BN}-\mathrm{MO}) / 2 \\
& \text { ここK, BN : 試料のボラン価( } \mathrm{mol} / \text { 試料 } 100 \mathrm{~g}) \\
& \text { MO : FIA 法によるオレフィン分を用いて計算した } \\
& \text { 試料 } 100 \mathrm{~g} \text { 中のモ/オレフィンのモル数 }
\end{aligned}
$$

Table 4 Analysis of olefin contents in a thermal cracked oil

\begin{tabular}{lc}
$\begin{array}{c}\text { Method of } \\
\text { analysis }\end{array}$ & $\begin{array}{c}\text { Olefin content as } \\
\text { monoolefin mol/100 } \mathrm{g} \\
\text { of sample }\end{array}$ \\
\hline Borane method & 0.123 \\
Bromine method & 0.265 \\
Iodine method & 0.144
\end{tabular}

Table 5 Weight ratios of unsaturated hydrocarbons in a sample used for FIA and borane methods

\begin{tabular}{lcc} 
Compound & $\begin{array}{c}\text { Content } \\
(\text { wt \%) }\end{array}$ & $\begin{array}{c}\text { Specific } \\
\text { gravity } \\
\left(20 / 4^{\circ} \mathrm{C}\right)\end{array}$ \\
\hline Toluene & 25.1 & 0.866 \\
1,7-Octadiene & 4.8 & 0.734 \\
1-Dodecene & 50.1 & 0.760 \\
$n$-Dodecane & 20.0 & 0.749
\end{tabular}

8) UOP Laboratory Test Method 326-65. 
Table 6 Analytical result of the sample shown in Table 5 by FIA method

\begin{tabular}{lcccc} 
& $\begin{array}{l}\text { Content } \\
\text { (vol \% } \\
\text { by FIA) }\end{array}$ & $\begin{array}{c}\text { Specific } \\
\text { gravity } \\
\left(20 / 4^{\circ} \mathrm{C}\right)\end{array}$ & $\begin{array}{c}\text { Content } \\
(\text { wt } \%)\end{array}$ & $\begin{array}{c}\text { Relative } \\
\text { error } \\
(\%)\end{array}$ \\
\hline Aromatics & $27.8^{a)}$ & $\left.0.842^{d}\right)$ & 30.0 & +0.3 \\
Olefins & $52.1^{b)}$ & 0.760 & 50.7 & +1.2 \\
Saturates & $20.1^{c)}$ & 0.749 & 19.3 & -3.5
\end{tabular}

a)b)c) Mean of five measured values.

a) The standard deviation $(\sigma)$ is 0.14 .

b) The standard deviation $(\sigma)$ is 0.33 .

c) The standard deviation $(\sigma)$ is 0.36 .

d) Obtained by measuring the mixture of $25.1 \mathrm{~g}$ of toluene and $4.8 \mathrm{~g}$ of 1,7 -octadiene.

Table 7 Borane number of the sample shown in Table 5

\begin{tabular}{cccc} 
& $\begin{array}{c}\text { Theoretical }^{a)} \\
a\end{array}$ & $\begin{array}{c}\text { Found } \\
b\end{array}$ & $\begin{array}{c}\text { Relative error } \\
(\%) \\
(b-a) / a \times 100\end{array}$ \\
\hline Borane number & 0.386 & $0.384^{b)}$ & -0.5
\end{tabular}

a) Theoretical value $=50.1 / 168+2 \times 4.8 / 110=0.386(\mathrm{~mol})$.

b) Mean of five measured values. The standard deviation $(\sigma)$ is 0.0009 .

標準試料中のジオレフィン量として，4.5 wt \% が得られ, 理論 值 $4.8 \mathrm{wt} \%$ とかなりよい一致を示している。

この結果から，ボラン法と FIA 法を組み合わせて，モノオレ フィンおよびジオレフィンの定量分析が可能であることがわか る。

な括，FIA 法に和いて，ジオレフィンがアロマティックス分 として定量されることを確認するために，FIA 分析において， 展開後のシリカゲルカラムからイソプロピルアルコールを用いて 溶出したアロマティックス，オレフィン拉び飽和分の各留分を GLC（カラム FFAP/Neopack $1 \mathrm{~A}, 2 \mathrm{~m}$, カラム温度 $70^{\circ} \mathrm{C}$ ) で分 析した。その結果, アロマティックス分にトルェンと 1,7-オク
Table 8 Content of diolefin in the sample listed in Table 5 obtained by borane method and FIA method

\begin{tabular}{|c|c|c|c|c|}
\hline Compound & $\begin{array}{l}\text { Molecular } \\
\text { weight }\end{array}$ & $\begin{array}{c}\mathrm{Mol} / 100 \mathrm{~g} \\
\text { of } \\
\text { sample }\end{array}$ & wt $\%$ & $\begin{array}{c}\text { Relative } \\
\text { error } \\
(\%)\end{array}$ \\
\hline 1-Dodecene & 168 & $\begin{array}{c}0.302 \\
\text { (by FIA) }\end{array}$ & 50.7 & +1.2 \\
\hline 1,7 -Octadiene & 110 & $\left.0.041^{a}\right)$ & $4.5^{b)}$ & -6.3 \\
\hline
\end{tabular}

a) Mol of 1,7 -octadiene $/ 100 \mathrm{~g}$ of sample $=(0.384-0.302) /$ $2=0.041$.

b) The standard deviation $(\sigma)$ is 0.077 .

タジェンが含有され，オレフィン分に 1-ドデセンが，飽和分に nードデカンが含有されていることを認めたので付記する。

\section{4 結 論}

nードデカンと 1 -ドデセンと $\alpha$-メチルナフタレンの混合物に ついて, ハイドロボレーションーメタノリシスによる本ボラン法 が簡便な精度の高いオレフィンの分析法であることを確かめた。 臭素価拉よ゙ョウ素価はアロマティックスなどの影響を受け，乙 かる有色のサンプルについては，分析が困難であるが，本ボラン 法はそのような欠点を有さないので, 臭素価およびョウ素洒より も適用範囲の広い有効な分析法であるといえる。また，本法は C-C 二重結合の全含有量を定量するため, ジオレフィンをアロ マティックス分として定量する FIA との租み合わせにより, ジ オレフィンを定量できることも報告した。

本研究の発表を許可された日本鉱業株式会社中央研究所長伊吹 正美氏に深謝致します。臭素価，ヨウ素価扰よび FIA による才 レフィンの分析に協力していたたいた同社中央研究所石油試験室 田藤光夫室長拈よび鈴木 達, 三瓶 正の両技師に深く感謝しま 寸。

（1973 年 4 月, 日本化学会第 28 春季年会発表）

\title{
A New Quantitative Determination of Olefins by Hydroboration- Methanolysis Method
}

\author{
Hiromi Ozaki*, Toshitake Ohtaki**, \\ Michiharu Makita* and Akira Suzuki*** \\ * Technical Research Center, Nippon Mining Company; Niizo, \\ Toda-shi 335 Japan \\ ** Petroleum Division, Nippon Mining Company ; Akasaka, Minato-ku, \\ Tokyo 170 Japan \\ *** Department of Applied Chemistry, Hokkaido University; \\ Sapporo-shi 060 Japan
}

A new quantitative analytical procedure of olefins in a mixture of hydrocarbons using hydroboration-methanolysis method is described.

After hydroboration of olefins in a mixture of hydrocarbons with diborane, methanol was added to decompose the excess hydrides. From the volume of hydrogen gas thus generated, the amount of olefins in the sample was calculated.

Although bromine, iodine and fluorescent indicator adsorption procedures are well known as analytical procedures of olefins, these are not applicable for colored samples. In addition, bromine and iodine methods usually give larger values than the theoretical values when aromatics and isoolefins are contained in samples tested. In contrast, it was accurate data. The olefins in a thermal cracked oil of an atmospheric residual oil were analyzed by the method. 
Finally, the determination of diolefin contents in a mixture containing monoolefins was proposed, based on the facts that fluorescent indicator adsorption technique analyzes diolefins, not as olefins but as aromatics, and that the present method gives all olefins as olefin contents.

（日本化学会誌，1974，（2）, p. 291 296）

\section{酶酸-酰酸ナトリウム緩衝溶液からの希土類元素の}

\section{溶媒抽出之協同効果}

(1973 年 5 月 30 日 受 理)

矢野良子*. 河野直子*. 近藤洋子**. 長島弘三*

水相中の $\mathrm{La}^{3+}, \mathrm{Gd}^{9+}, \mathrm{Yb}^{3+}\left(\sim 10^{-3} \mathrm{~mol} / l\right)$ を 10 80 倍量の TTA およよ゙ 0 10 倍量の中性塩基 (TBP, TOPO, TBPO, $\alpha-$ および $\gamma$-ピコリン) を用いてキシレン相へそれぞれ抽出した。水相は酢

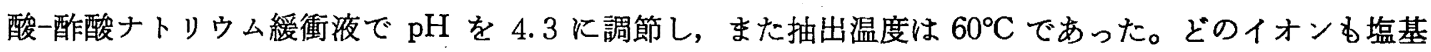
による協同勃果が認められ，その大きさは M-TTA-TBP 系で $\mathrm{La}^{3+}>\mathrm{Gd}^{3+}>\mathrm{Yb}^{3+}$ であり， $\mathrm{Gd}^{3+}$ TTA-塩基系では $\mathrm{TOPO}, \mathrm{TBPO}>\mathrm{TBP}>\gamma-$ おび $\alpha$-ピコリンの順であった。緩衝液中の酢酸は 水相中で金属に配位しているため抽出反応に関与する。有機相中でぞのイオンの場 合も $\mathrm{M}(\mathrm{TTA})_{2}$ ・ $\left(\mathrm{CH}_{3} \mathrm{COO}\right)$ ・TBP のような抽出錯体が生成した。 $\mathrm{La}^{3+}$ と $\mathrm{Yb}^{3+}$ ではそれぞれイオン半径が大きいこと と小さいことに原因すると思われる他の型の錯体も同時に生成していることが認められた。 $\mathrm{Gd}^{3+}-$ TTA-ピコリン系では $\mathrm{Gd}(\mathrm{TTA})_{s} \cdot$ Pic. が抽出錯体と.して認められ，このとさ $\alpha$ - および $\gamma$-ピコリン の間で分配比に差異がなかった。ピコリンは電子供与性の大きい TBP と異なって金属に直接配位して いないと仮定して説明した。

\section{1 緒言}

希土類元素の溶媒抽出とその協同効果, とくにいろいろの $\beta-$ ジヶトンと中性塩基（リン酸エステル，有機リン酸化物など）と による協同効果については多くの研究がなされ議諭されてきて いる。従来の研究の多くは 10-8 $\mathrm{mol} / l$ 程度のトレーサー量の 金属イオンの水溶液から金属イオンにくらべて大過剩（100〜 1000 倍）の $\beta$-ジヶトンや中性塩基を含む有機溶媒に抽出すると いら方法がとられている。その結果，多くの場合抽出錯体として $\mathrm{MA}_{3} \cdot \mathrm{B}_{n}{ }^{1) \sim 5)}(\mathrm{M}:$ 金属， $\mathrm{A}: \beta$-ジケトン, $\mathrm{B}$ : 中性塩基）の生成 が認められ，これが $\mathrm{MX}_{3}$ より抽出されやすいことが協同効果の 原因と考えられてきた。これに対して，比較的電子供与性の高い 有機りン酸化物の場合には， $\beta$-ジヶトンを配位圏から追い出して

* 東京教育大学理学部化学教室, 112 東京都文京区大塚

** 現在 日本ロシ二株式会社, 247 鎌倉市暒原

1) H. Irving, D. N. Edgington, J. Inorg. Nucl. Chem., 21, $169(1961)$.

2) T. V. Healy, ibid., 19, 314(1961).

3) T. Sekine, M. Ono, Bull. Chem. Soc. Jap., 38, 2087 (1965).

4) T.Sekine, D. Dyrssen, J.Inorg. Nucl.Chem., 29, 1481 (1967).

5) T.Sigematsu, M. Tabushi, M. Matsui, T. Honjo, Bull. Chem.Soc. Jap., 40, 2807(1967).
かわりに数個配位し, 足りない電荷を水相中の陰イオンの配位, またはイオン対生成によって補らといら抽出反応す見られる。こ の場合 $\mathrm{MA}_{2} \mathrm{X} \cdot \mathrm{B}_{2}{ }^{1)}$ や $\left(\mathrm{MA}_{2} \mathrm{~B}_{5}\right)^{+} \mathrm{X}^{-6) 7)}(\mathrm{X}$ は陰イオン) が抽出さ れる錯体の形である。また，リン酸トリブチル（以下 TBP と略 記する）のような中性塩基自身を溶媒，または非常に高濃度（30 $\%$ で用いた場合には $\left.\mathrm{M}\left(\mathrm{NO}_{3}\right)_{3} \cdot(\mathrm{TBP})_{3}^{8}\right)^{8}$ のような錯体の生成も 認められている。

希土類元素イオンの半径の影響については, 同し 3 価のイオン についてイオン半径が大きいほど $\beta$-ジヶトンのみによる抽出定 数は小さいが中性塩基による 付加鍇体生成の定数は大きく，協 同効果による分配比の増大の割合が大きいことが観察されてい

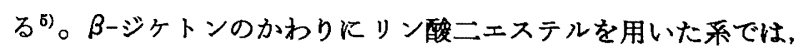
原子番号 $64(\mathrm{Gd})$ 付近を境としてイオン半径の大きい方たけに 協同効果があらわれるといら報告もある9。

イオン半径の協同効果に対する影響は金属イオンに対して少過 剩の抽出試楽しか含まないような条件のるとでいっそらはっきり

6) T. Taketatsu, N. Toriumi, J. Inorg. Nucl. Chem., 31, 2235(1969).

7) T. Taketatsu, N. Okura, Bull. Chem. Soc. Jap., 44, 2430(1971).

8) G. F. Best, E. Hesford, H. A.C. Mckay, J. Inorg. Nucl. Chem., 12, 136(1959).

9) M. Zangen, ibid., 25, 1051(1963). 